\title{
Sex Ratio and Sex Reversal in Two-year-old Class of Oyster, Crassostrea gigas (Bivalvia: Ostreidae)
}

\author{
Jung Jun Park', Hyejin Kim², Seung Wan Kang', Cheul Min $\mathbf{A n}^{4}$, \\ Sung-Ho Lee ${ }^{5}$, Myung Chan Gye ${ }^{6}$ and Jung Sick Lee ${ }^{2, \uparrow}$ \\ ${ }^{1}$ Aquaculture Management Division, Aquaculture Research Institute, NFRDI, Busan 619-902, Korea \\ ${ }^{2}$ Dept. of Aqualife Medicine, Chonnam National University, Yeosu 550-749, Korea \\ ${ }^{3}$ Gyeongsangnam-do Fisheries Resources Research Institute, Tongyeong 615-118, Korea \\ ${ }^{4}$ Biotechnology Research Division, Aquaculture Research Institute, NFRDI, Busan 619-902, Korea \\ ${ }^{5}$ Dept. of Green Life Science, Sangmyung University, Seoul 110-743, Korea \\ ${ }^{6}$ Dept. of Life Science, College of Natural Sciences, Hanyang University, Seoul 133-791, Korea
}

\begin{abstract}
The sex ratio (F:M) in the same population of oyster, Crassostrea gigas at the commencement of the study (2007) was 1:1.0, but changed to 1:2.8 by the end of the study (2008). The sex reversal rate in two-year-old oysters was $40.2 \%$. Specifically, female to male sex reversal rate was $66.1 \%$, which is higher than the male to female sex reversal rate of $21.1 \%$. The sex reversal pattern of C. gigas appears to go from male $\Rightarrow$ female $\Rightarrow$ male, and as such is determined to be rhythmical hermaphroditism.
\end{abstract}

Key words : Crassostrea gigas, Two-year-old class, Sex reversal, Rhythmical hermaphroditism

Sex reversal has indirectly and directly been confirmed in several bivalve species (Orton, 1933; Coe, 1943; Gould, 1952; Osanai, 1975; Guo et al., 1998; Kasyanov, 2001; Lee et al., 2012a, b). Examples of sex ratio changes in accordance with size at the level of population has been found in Ostrea virginica (Galtsoff, 1937), Mercenaria mercenaria (Eversole, 2001) and Crassostrea gigas (Gosling, 2004). The oyster, C. gigas, displays multiple sexual characteristics in which protandric sex change, dioecy and hermaphroditism are displayed concurrently. It has also been shown that $C$. gigas female ratio increases with age as the result of sex reversal from male to female (Guo et al., 1998). According to preliminary study, $C$. gigas displayed differences in sex ratio in accordance with shell size. Although the male ratio was high in the one-year-old class, the female ratio was higher in the

\footnotetext{
${ }^{4}$ Corresponding author: Jung Sick Lee, Dept. of Aqualife Medicine, Chonnam National University, Yeosu 550-749, Korea. Phone : +82-61-659-7172, Fax: +82-61-659-7172, E-mail: 1js@chonnam.ac.kr
}

two-year-old class, with the male ratio becoming higher once again in three-year olds. The aim of this study was to verify the pattern of sex reversal in two- year-old oyster, C. gigas, with the anticipation that sex reversal pattern of this species would differ in accordance with age.

Oysters used in sex ratio analysis were collected from the Sangju seashores in the south sea of Korea $(\mathrm{N}$ $34^{\circ} 42^{\prime} 49^{\prime \prime}$, E $\left.127^{\circ} 59^{\prime} 13^{\prime \prime}\right)$ in July 2006. 459 specimens of $C$. gigas were used in the sex ratio analysis ( $\mathrm{SH}$ : 23.5-135.7 mm). Oysters used in sex reversal confirmation were two-year-olds (14 months) of $88.7 \mathrm{~mm}$ in average shell height $(\mathrm{n}=293)$. Collection and rearing of the oysters in wild conditions for identification of sex reversal was carried out in the same location. Confirmation of sex reversal was carried out in accordance with the methods of Lee et al. (2010). 1) germ cell aspiration and sex verification, 2) sex tagging on the shell, 3) rearing in the wild condition (from July 2007 to July 2008), and 4) sex reversal was verified using histological analysis.

Sex ratio $(F: M)$ for the entire population $(n=459)$ was 
1:1.5. However, sex ratio was found to be different when the oysters were divided into groups according to shell height $(\mathrm{SH})$ in intervals of $10.0 \mathrm{~mm}$. The sex ratio of individuals with $\mathrm{SH} \leq 70.0 \mathrm{~mm}$ was 1:2.7 ( $\mathrm{n}=52: 140)$, showing a higher proportion of males. In contrast, the sex ratio of individuals with $\mathrm{SH}$ between 70.1-100.0 mm was 1:0.9 ( $n=103: 88)$, exhibiting a higher proportion of females. This pattern was reversed again in the sex ratio of individuals with $\mathrm{SH} \geq 100.1 \mathrm{~mm}$ was $1: 1.5$ ( $\mathrm{n}=$ $30: 46$ ), where a higher proportion of males were observed once again (Table 1).

The average SH of oysters at the commencement of fieldwork (2007) was $88.7 \mathrm{~mm}$, while at the end-point of fieldwork (2008) SH was $99.2 \mathrm{~mm}$. Sex ratio at the start of fieldwork was 1:1.0 $(n=143: 150)$. However, the sex ratio of 132 individuals at the end of fieldwork, with the exception of oysters for which identification of sex was not possible, was 1:2.8 $(n=35: 97)$, thereby illustrating significant higher ratio of male (Table 2).

Rate of sex reversal in two-year-old oysters was $40.2 \%$ ( $n=53 / 132)$. Among these, $66.1 \%$ exhibited conversion of sex from female to male $(n=37 / 56)$, while $21.1 \%$ $(n=16 / 76)$ changed from male to female, thereby illustrating higher sex reversal rate from female to male (Table 3 ).

Sex reversal research of bivalves has traditionally been conducted on oysters. Literature does point to the fact that the proportion of males is higher at the early stage, with increase in the proportion of females arising through sex reversal as the oyster gets older (Orton, 1933; Galtsoff, 1964; Thompson et al., 1996; Guo et al., 1998).

Table 1. Sex ratio with shell size of oyster, Crassostrea gigas

\begin{tabular}{|c|c|c|c|c|c|c|}
\hline \multirow{2}{*}{ Shell height (mm) } & \multicolumn{3}{|c|}{ Number } & \multirow{2}{*}{ Sex ratio (F:M, \%) } & \multirow{2}{*}{ Chi-square } & \multirow{2}{*}{$P$ value } \\
\hline & Total & Female & Male & & & \\
\hline$\leq 30.0$ & 5 & 1 & 4 & $1: 4.0(20.0: 80.0)$ & 1.80 & 0.18 \\
\hline $30.1 \sim 40.0$ & 14 & 2 & 12 & $1: 6.0(14.3: 85.7)$ & 7.14 & 0.008 \\
\hline $40.1 \sim 50.0$ & 39 & 7 & 32 & $1: 4.8(17.9: 82.1)$ & 16.03 & $<0.001$ \\
\hline $50.1 \sim 60.0$ & 60 & 16 & 44 & $1: 2.8(26.7: 73.3)$ & 13.07 & $<0.001$ \\
\hline $60.1 \sim 70.0$ & 74 & 26 & 48 & $1: 1.8(35.1: 64.9)$ & 6.54 & 0.011 \\
\hline $70.1 \sim 80.0$ & 84 & 45 & 39 & 1:0.9 (53.6:46.4) & 0.43 & 0.513 \\
\hline $80.1 \sim 90.0$ & 57 & 32 & 25 & $1: 0.8(56.1: 43.9)$ & 0.86 & 0.354 \\
\hline $90.1-100.0$ & 50 & 26 & 24 & $1: 0.9(52.0: 48.0)$ & 0.08 & 0.777 \\
\hline $100.1 \sim 110.0$ & 29 & 11 & 18 & $1: 1.6(37.9: 62.1)$ & 1.69 & 0.194 \\
\hline $110.1 \sim 120.0$ & 27 & 10 & 17 & 1:1.7 (37.0:63.0) & 1.82 & 0.178 \\
\hline $120.1 \sim 130.0$ & 11 & 5 & 6 & $1: 1.2(45.5: 54.5)$ & 0.09 & 0.763 \\
\hline $130.1 \leq$ & 9 & 4 & 5 & 1:1.3 (44.4:55.6) & 0.11 & 0.739 \\
\hline Total & 459 & 185 & 274 & $1: 1.5(40.3: 59.7)$ & 17.257 & $<0.001$ \\
\hline
\end{tabular}

Table 2. Sex ratio change with age in same population of oyster, Crassostrea gigas

\begin{tabular}{cccccccc}
\hline \hline Year & $\begin{array}{c}\text { Shell height } \\
(\mathrm{mm})\end{array}$ & Total & Female & Male & $\begin{array}{c}\text { Sex ratio } \\
\text { (F:M) }\end{array}$ & Chi-square & $P$ value \\
\cline { 3 - 4 } $\begin{array}{c}2007 \\
\text { (One-year-old class) }\end{array}$ & 88.7 & 293 & 143 & 150 & $1: 1.0$ & 0.17 & 0.683 \\
\hline $\begin{array}{c}2008 \\
\text { (Two-year-old class) }\end{array}$ & 99.2 & 132 & 35 & 97 & $1: 2.8$ & 29.12 & $<0.001$ \\
\hline
\end{tabular}


Table 3. Sex reversal rate in two-year-old class of oyster, Crassostrea gigas

\begin{tabular}{cccccc}
\hline \hline \multirow{2}{*}{ Total $(\%)$} & \multicolumn{3}{c}{ Female $(\mathrm{F})$} & \multicolumn{3}{c}{ Male $(\mathrm{M})$} \\
\cline { 2 - 5 } \cline { 5 - 6 } & $\mathrm{F} \rightarrow \mathrm{F}(\%)$ & $\mathrm{F} \rightarrow \mathrm{M}(\%)$ & $\mathrm{M} \rightarrow \mathrm{M}(\%)$ & $\mathrm{M} \rightarrow \mathrm{F}(\%)$ \\
\hline $40.2(\mathrm{n}=53 / 132)$ & $33.9(\mathrm{n}=19 / 56)$ & $66.1(\mathrm{n}=37 / 56)$ & & $78.9(\mathrm{n}=60 / 76)$ & $21.1(\mathrm{n}=16 / 76)$ \\
\hline
\end{tabular}

Although manifestation of morphological sex and activation of bivalve gonads are in principle genetically influenced, they are also affected by environmental and biological factors (Coe, 1938; Gould, 1952; Guo et al., 1998).

In the case of Pomacea canaliculata, C. gigas and Mytilus sp., an oligogenic sex determination method was used, which is a mechanism that results in highly diversified sex ratio and sex determination by small number of genes (Guo et al., 1998; Yusa, 2007). Changes in sex ratio due to exposure to pollutants, such as EDCs (endocrine disrupting chemicals) during the inactive season, have also been reported in Mya arenaria (Gagné et al., 2003), Gomphina veneriformis (Lee \& Park, 2007; Ju et al., 2009) and Scapharca broughtonii (Lee et al., 2009).

Guo et al. (1998) found the female ratio of C. gigas to be $37 \%, 55 \%$ and $75 \%$ in one-year, two-year and threeyear old oysters, respectively. This was assumed to be as a result of sex reversal from male to female. In addition, the results of the above cited study illustrated genetic regulation of sex with the paternal effect in the sex reversal of the individuals, showing concordance with the single-locus model of primary sex determination with dominant male allele (M) and protandric female allele (F). MF is the true male while FF is the protandric female that can undergo sex reversal. It was presumed that the sex reversal ratio of FF individuals is the result of influence from the secondary genes and/or environmental factors.

Although the above report did not mention sizes, it is presumed that 'adult' refers to two-year-olds.

The results of our preliminary study showed diverse differences in sex ratio in accordance with the sizes of C. gigas. Although the proportion of males was higher in the one-year-old class, that of females was higher in the two-year-old class, thereby illustrating similar results with Guo et al. (1998). However, the proportion of males was higher in the three-year-old class. Such difference in sex ratio was determined as the result of higher sex reversal from female to male $(66.1 \%)$ than from male to female $(21.1 \%)$ in two-year-old oysters.

Coe (1943) presented the following four patterns of hermaphroditism in bivalves on the basis of sequence of reproductive events: 1) functional hermaphroditism, 2) consecutive hermaphroditism, 3) rhythmical hermaphroditism, and 4) alternative hermaphroditism. Among these, 2), 3) and 4) are results of determination of sex at a point in life cycle as the standard point and refer to the species generally described as gonochoristic that undergo sex reversal.

In this study, although sex reversal was identified in male and female of two-year-old oysters, the sex reversal rate from female to male was higher than from male to female. Therefore, when our results are compared with that of Guo et al. (1998), it is evident that the sex reversal pattern of oyster, C. gigas appears to go from male $\Longrightarrow$ female $\Longrightarrow$ male, and the sex is rhythmical hermaphroditism.

\section{ACKNOWLEDGEMENT}

This research was supported by Basic Science Research Program through the National Research Foundation of Korea (NRF) funded by the Ministry of Education, Science and Technology (2012-0004670).

\section{REFERENCES}

Coe WR (1938) Conditions influencing change of sex in mollusks of the genus Crepidula. J Exp Zool 77:401-424.

Coe WR (1943) Sexual differentiation in mollusks. I. 
Pelecypods. Quart Rev Biol 18:154-164.

Eversole AG (2001) Reproduction in Mercenaria mercenaria. In: Kraeuter JN, Castagna M (eds.) Biology of the Hard Clam. Elsevier, New York, pp. 221-260. Gagné F, Blaise C, Pellerin J, Pelletier E, Douville M, Gauthier-Clerc S, Viglino L (2003) Sex alteration in soft-shell clams (Mya arenaria) in an intertidal zone of the Saint Lawrence River (Quebec, Canada). Comp Biochem Physiol C 134:189-198.

Galtsoff PS (1937) Observations and experiments on sex change in the adult American oyster, "Ostrea virginica". Collecting Net 12:187.

Galtsoff PS (1964) The American oyster Crassostrea virginica Gmelin. Fish Bull 64:1-480.

Gosling E (2004) Bivalve Molluscs: Biology, Ecology and Culture. Blackwell Science, Oxford, pp 1-443.

Gould HN (1952) Studies on sex in the hermaphrodite mollusk Crepidula plana. Part IV. Internal and external factors influencing growth and sex development. J Exp Zool 119:93-163.

Guo X, Hedgecock D, Hershberger WK, Cooper K, Allen SK Jr (1998) Genetic determinants of protandric sex in the Pacific oyster, Crassostrea gigas Thunberg. Evolution 52:394-402.

Ju SM, Park JJ, Lee JS (2009) Induction of intersex and masculinization of the equilateral venus, Gomphina veneriformis (Bivalvia: Veneridae) by zinc. Anim Cells Syst 13:339-344.

Kasyanov VL (2001) Reproductive Strategy of Marine Bivalves and Echinoderms. Science Publishers Inc., Enfield, pp 1-229.

Lee JS, Cho HS, Jin YG, Park JJ, Shin YK (2009) Reproductive disrupting effect of organotin compound in the ark shell, Scapharca broughtonii (Bivalvia: Arcidae). Anim Cells Syst 13:223-227.

Lee JS, Ju SM, Park JS, Jin YG, Shin YK, Park JJ
(2010) Germ cell aspiration (GCA) method as a nonfatal technique for sex identification in two bivalves (Gomphina veneriformis and Tegillarca granosa). Dev Reprod 14:7-11.

Lee JS, Ku K, Kim H, Park JS, Park JJ, Shin YK, Jeon MA (2012a) Indirect evidence on sex reversal with sex ratio of Tegillarca granosa (Bivalvia: Arcidae) and Ruditapes philippinarum (Bivalvia: Veneridae). Dev Reprod 16:177-183.

Lee JS, Park JJ (2007) Risk assessment of nonylphenol using the sex ratio, sexual maturation, intersex and lipofuscin accumulation of the equilateral venus, Gomphina veneriformis (Bivalvia: Veneridae). J Kor Fish Soc 40:16-23.

Lee JS, Park JS, Shin YK, Lee YG, Park JJ (2012b) Sequential hermaphroditism in Manila clam Ruditapes philippinarum (Bivalvia: Veneridae). Invert Reprod Dev. DOI: 10.1080/07924259.2012.717109.

Orton JH (1933) Observations and experiments on sexchange in the European oyster (O. edulis). Part III. On the fate of unspawned ova. Part IV. On the change from male to female. J Mar Biol Ass UK 6:1-53. Osanai K (1975) Seasonal gonad development and sex alteration in the scallop Patinopecten yessoensis. Bull Mar Biol Stn Asamushi 15:81-88.

Thompson RJ, Newell RIE, Kennedy VS, Mann R (1996) Reproductive process and early development. In: Kennedy VS, Newell RIE, Eble AF (eds.) The Eastern Oyster Crassostrea virginica. Maryland Sea Grant, Maryland, pp 335-370.

Yusa Y (2007) Causes of variation in sex ratio and modes of sex determination in the Mollusca - an overview. Amer Malac Bull 23:89-98.

(Received 2 October 2012, Received in revised form 30 October 2012, Accepted 14 November 2012) 